\title{
NAME SIGNS FOR HEARING PEOPLE ${ }^{1}$
}

\section{Liina Paales}

\begin{abstract}
The article will discuss personal name signs given by members of the Deaf community to hearing people. The main categories of Estonian personal name signs' formation will be introduced. There are four categories of personal name signs in Estonian Sign Language: 1) arbitrary (initialised) name signs; 2) descriptive name signs; 3) initialised-descriptive name signs or 4) loan/borrowed name signs.
\end{abstract}

The nature of personal name signs has been considered in the context of onomastics and folkloristics. Here the issue is about defining personal name signs as nicknames or as official names. In the context of sign language intercourse personal name signs have an official status and are applied in formal situations in Deaf communities.

In the present article, name signs of Deaf-related and Deaf community nonrelated public figures of the dominant hearing culture have been explored. Three key sources have been exploited for this research: 1) publications (international personal name signs studies; printed and electronic media); 2) oral (signed) and written information from Deaf people, sign language interpreters and name signs researchers; 3) manuscripts.

A large number of name signs of hearing people have been collected by the author from different sign languages - Estonian Sign Language, Russian Sign Language, Finnish Sign Language and German Sign Language, etc. A set of personal name signs of Deaf school teachers, sign language interpreters, sign language researchers, politicians, athletes, and other public figures has been represented, and several name signs of religious figures.

There is no linguistic difference in forming name signs for Deaf or hearing people, however, there is a cultural difference between Deaf communities and dominant hearing societies revealed in name signs' heritage and perception.

Key words: American Sign Language, Chinese Sign Language, culture contacts, Deaf cultures, Estonian Deaf community, Estonian Sign Language, Finnish Sign Language, French Sign Language, German Sign Language, hearing people, New Zealand Sign Language, nicknames, personal name, personal name signs, Philippine Sign Language, Russian Sign Language, Thai Sign Language

\section{INTRODUCTION}

Estonian Sign Language (ESL) is a visual-gestural language. The core community of ESL users consists of approximately 1400-1500 inherent or pre-speech Deaf people (Hollman 2010: 28). One aspect of Deaf communication, finger 
spelling of the alphabet of spoken language ${ }^{2}$ (Fig. 1) was already introduced by Friedrich Reinhold Kreutzwald (1803-1882), a public figure of the Estonian national awakening period, writer and physician, to local people approximately two decades before our first school for Deaf was established. In the popular science picture magazine Ma-ilm ja mõnda, mis seal sees leida on ('The world and something of what it contains') published in 1849 he referred to hand configurations of manual alphabet as "sõrmekeele-pookstavid" (letters of fingerlanguage). The illustration added to the text resembles the British two-handed manual alphabet. ${ }^{3}$ Kreutzwald emphasised that a hearing person should not think of the manual alphabet as a joke as it helps when communicating with Deaf people (Kreutzwald 1849: 123-125).

Lutheran pastor Ernst Sokolovski established the first Estonian school for the Deaf in Vändra in 1866. According to some references Deaf individuals were taught in Estonia as early as the 17th century (Kotsar \& Kotsar 1996: 8). Currently, hearing impaired children are educated in Tartu Hiie School and Tallinn Helen School by using various teaching methods. Estonian Deaf people have their own wide network of organisations, with the umbrella organisation being the Estonian Association of the Deaf, which has regional representations across the republic. In addition, there is the Estonian Deaf Sport Union

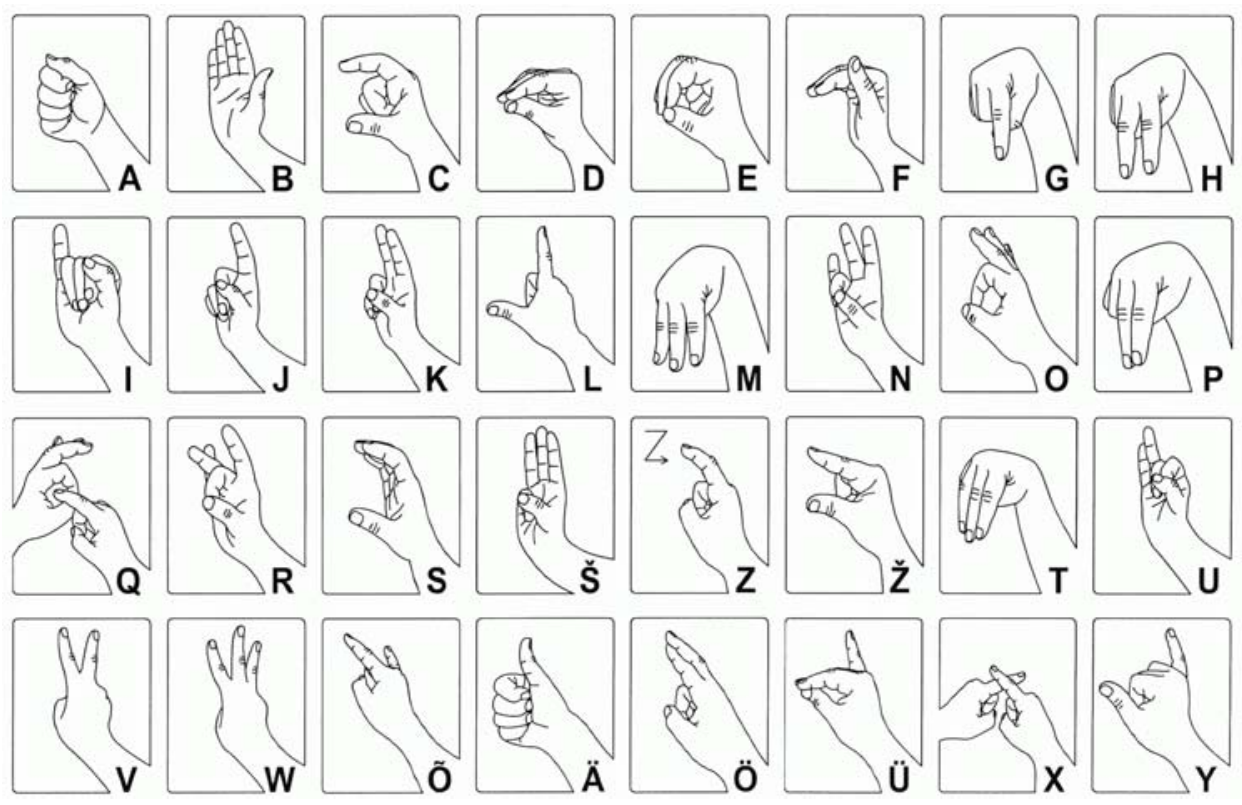

Figure 1. Contemporary Estonian finger alphabet (Illustration: I. Kaunissaar). 
with its regional divisions and the Estonian Deaf Organization for Youth. Deaf people are also involved in the activities of relevant work groups of several Christian denominations.

In recent decades the hearing and Deaf communities in Estonia have shown signs of convergence. During the 1980s-1990s, new fields emerged in the research of Estonian social and cultural sciences: Estonian Sign Language, Deaf history, Deaf culture and Deaf folklore. In addition to defining Deaf people as a group of people with hearing impairment and special needs, they are also defined as a language minority. The world of sign-language users attracts more and more interest from those outside the Deaf community, i.e. people who have no direct personal or family contact with Deaf people.

In the last decades of the 20th century both the opinion of the majority society towards Estonian Sign Language, as well as Estonian Sign Language itself, have undergone major changes. The former (predominant) view of signing as a primitive means of communication has, due to cooperation between the hearing society and the Deaf community, been transformed into national recognition of sign language. ${ }^{4}$

Estonian Television produced sign language programmes intended especially for Deaf people in the late 1980s and the first half of the 1990s. Sign language interpretation of the news became available on TV as of 1998. In 2009 , interpretation on TV was discontinued and broadcasting of sign language news was resumed on Channel 2 of Estonian Television, with news prepared and reported by Deaf journalists.

Sign language interpretation services have been developed in Estonia based on the need to improve communication between Deaf and hearing people. Since 2006 the University of Tartu has provided training of sign language interpreters. The professional association of Estonian Sign Language interpreters is a member of the European Forum of Sign Language Interpreters (EFSLI). ${ }^{5}$

\section{SOURCES OF RESEARCH}

This article focuses on cultural contacts between the Deaf community and the hearing community in a broader sense and more specifically concerns the language heritage of Deaf people, onomastics, and the study of personal name signs. The purpose is to introduce, by example of particular personal name signs, the general features of a Deaf heritage, world view and language formation. The object of this study encompasses name signs attributed to hearing people by the Deaf community. The author discusses the following issues: 1) study of name signs at the international level and in Estonia; 2) categories 
of name signs; 3) definitions of person-denoting signs in an onomastic context (personal name sign/ nickname/ personal name); 4) methods of formation of Estonian person-denoting signs; 5) name signs of hearing people in Estonian and other national Deaf communities. The collection of name signs allows access to the name heritage of Deaf people.

The overview provided in this article is based on the research on national personal name signs and the author's previous works regarding Estonian personal name signs. Name signs of hearing people are divided into three groups: 1) name signs of people related to the Deaf community; 2) name signs of public figures in the hearing society; 3) name signs of religious figures. The subdivisions of the first two groups are based either on the field of activity of the person in question, or his or her specific relationship with Deaf people, and the third group reviews ten name signs related to Christianity and one name sign related to Buddhism.

The name signs indicated in the article were selected in a way that they would represent different groups of people and name-forming methods. The article draws on a total of 112 name signs attributed to 103 people (see Appen$\operatorname{dix} 1^{6}$ ). There were 7 people with two or more name signs ${ }^{7}$. There was one socalled personal family name sign, where the same name sign was used for the entire family. Family members were distinguished by using attributive signs (e.g. WIFE, DAUGHTER). In addition to the Estonian Sign Language this article provides examples from Finnish, Russian, German, French, American, Chinese, Philippine, Thai and New Zealand Sign Languages.

The name signs included in this article originate from various sources: 1) publications (international research on person-denoting signs, electronic and printed media); 2) oral and written information (obtained from Estonian Deaf people and sign language interpreters, information received by e-mail and drawings by German ethnographer Anne Uhlig and French ethnologist Yves Delaporte); 3) manuscripts (written notes in possession of the author, made on the basis of information collected from the Estonian Deaf community since $1995^{8}$, materials of the Deaf and hearing sign language interpreters' work group of the Estonian Bible Society).

A more critical approach is required when using the examples taken from foreign media, because the author had no opportunity to verify the use of these person-denoting signs in relevant sign languages. Estonian translations of such name signs (which represent more of an interpretation by the author) are presented in a gloss system. Estonian glosses are written in capital letters. 


\section{TERMINOLOGY, CLASSIFICATION AND RESEARCH HISTORY OF NAME SIGNS}

Name category is universal in linguistic terms. Different national sign languages have developed their own name systems. The terms used to denote names in Estonian Sign Language, are called viipenimi or synonymously, nimemärk 'name sign'. In other spoken languages the general terms include viittomanimi (in Finnish), name sign (in English), Namensgebärde (in German), and nom-signé (in French).

Name signs represent a viable language and heritage tradition, their formation and perception is based on visual information, historic cultural space, cultural beliefs of the group, and linguistic means of expression. The practice of using and forming name signs varies by communities.

This article focuses on personal name signs (isikuviipenimed or isikumärgid in Estonian, henkilöviittoma in Finnish, and persontecken in Swedish). In Estonian Sign Language the personal name sign is denoted by a simple sign VIIPLEMA+PILT [TO SIGN + PICTURE].

The pioneer of name sign research, Deaf linguist Samuel J. Supalla studied the person-denoting signs of American Deaf people (Supalla 1992). Personal name signs have been most frequently studied with regard to national sign language name systems, for instance, studies have been carried out in the field of person-denoting signs in Finnish (Rainò 2000, 2004, 2005), Swedish (Hedberg 1994), French (Delaporte 2002), and other sign languages. Less attention has been paid to place name signs and other name signs (e.g. ethnonyms), however, both personal name signs and place name signs have been studied in Estonia (Paales 2004, 2008, 2010).

\section{PERSON-DENOTING SIGNS IN THE CONTEXT OF ONOMASTICS}

The research regarding sign language name systems has mostly emphasised the formation methods of personal name signs and their role in shaping the cultural identity of Deaf people. Name signs have also been defined as part of Deaf folklore, a type of playful language creation or sign-lore of Deaf people (Klima \& Bellugi 1979: 319-339; Rutherford 1993: 129-135; Carmel 1996: 197200 ). In the context of onomastics the essence of person-denoting name signs has been analysed to a lesser extent.

When considering name signs in terms of onomastics, we have to ask which name category they belong to - thus, person-denoting signs are proper names; 
proper names are official names denoting people or personal names, and nicknames. In her article on the essence of different names, Kristin Vaik refers to the works of Sven Kala on Estonian nicknames, referring to the latter as all names that denote a particular person and differ from an official personal name (Vaik 2006).

Do personal name signs represent personal names or nicknames? Their classification into one or the other category is determined by various features. In the context of spoken language the name sign as visual-gestural differs from reference to a person's verbal name form (official, phonetic/written personal name) and this substantial fact provides a basis for defining name signs as nicknames.

Name researcher Peter McClure states in his work that nicknames refer to a person's character, appearance, behaviour or a certain event related to that person (McClure 1981: 65). Kathryn P. Meadow, who studied American name signs, relies on the research on children's linguistic humour and refers, among other authors, to D. J. Winslow, who divides children's nicknames into four groups: 1) physical peculiarities (such as spectacles, braces, racial features, etc.); 2) actual or assumed mental peculiarities; 3) nicknames based on social relations; 4) parody of the actual name of the child (Meadow 1977: 242).

These features are also characteristic of descriptive personal name signs one of the name sign categories - which contain elements that are common to nicknames and sometimes perceived as derogatory (e.g. indications of the appearance, character of the person denoted), and they are almost always translated into spoken languages as a nickname. At the same time, in signing communities, any type of personal name sign functions as proper name, i.e. assumes the role of an official name. It is possible that certain Deaf people are only known in the community by their personal name signs and the written name form is unknown. Deaf people use sign names both in daily communication and for public presentations (Rainò 2004: 10).

This essential problem has come to the attention of other name sign researchers as well: according to K. P. Meadow, the name signs can, in a way, be compared to nicknames, although their functions do not fully overlap (Meadow 1977: 243). Chinese name sign researchers Yau Shunchiu and He Jinxian ask a rhetorical question: if the name sign was defined as a nickname then should the reference person be tolerant of the derogatory name sign attributed to him or her? They claim that Chinese personal name signs undergo morphological changes, losing their originally transparent (derogatory) meaning (Yau \& He 1990: 249, 251-252).

In numerous Deaf communities, including Estonia, the process of name sign formation involves reference to a person's notable visible features (a mole, 
scar, missing limb, freckles, etc.). As a hearing person, a name researcher should not be prejudicial and judgmental or decide, based on such personal name signs, that Deaf people are insensitive and rude. Personal connotations embedded in name signs derive from the peculiarity of the world perception of a Deaf person and do not necessarily mean that they should be interpreted as negative or mean (McKee \& McKee 2000: 26).

If you ask whether a Deaf person "prefers" the official (written) name or name sign, then the preference is undoubtedly given to the name sign as it is a symbol of his/her own culture. Classification of personal name signs as a name category in terms of onomastics is an intriguing subject for further discussion.

\section{PERSONAL NAME SIGNS, PERSONAL NAMES AND NICKNAMES}

A personal name sign, personal name and nickname can be used to identify and differentiate proper names, but personal name signs and nicknames have an additional function to emphasise the feeling of togetherness. For instance, personal name signs reflect whether one belongs to the Deaf community or is related to it, and hearing people can also have their own name signs. Or, according to French ethnologist Yves Delaporte: even if Deaf people do not exist for you, you exist in their name system (Delaporte 2002: 207).

Thus, on the one hand, the moment of attributing a personal name sign signifies the entry of that person into the sign language community, by creating a connection with the history and language of the group. On the other hand, a name sign is a linguistically efficient personal denotation; a cultural anchor for coping both in the sign language community and hearing society. A person may have several different name signs with different social functions.

In comparison to a phonetic name the personal name does not function as a call sign. Deaf people have several other methods to attract the attention of their conversation partner (e.g. by waving or tapping the partner's shoulder or arm). When communicating, the name sign is used for denoting a third person. Signing of personal name signs may be accompanied by articulation of the phonetic name or mouth patterns motivated thereof. Personal name signs are mostly signed near the head, face, or chest; if a particular name sign has not yet been developed, finger spelling of the given name and/ or surname is used. ${ }^{9}$

Just like any other child, the children of Deaf people are also named by their parents after birth (in verbal/written form). As researchers of name signs 
from New Zealand have pointed out, phonetic names are not accessible in the signed discourse: it is difficult to teach their social and linguistic significance to Deaf children, as they cannot hear the pronunciation of these names (McKee \& McKee 2000: 9).

Usually Deaf children are given their personal name sign by their Deaf contemporaries at school. For example, Chinese researchers describe a situation, where the newcomers are given a name sign by older co-students at the school for Deaf (Yau \& He 1990: 245). When communicating with the members of Estonian Deaf community, it appears that most of them received their name sign while living in the boarding school - many name sign traditions are started at the Deaf school.

Based on the aforementioned we may say that nicknames and personal name signs are created on the same basis. They are generated in cooperation, interaction, and dialogue between the reference person and the denoting person (Vaik 2006: 88). K. Meadow, referring to the American Deaf community, points out three periods when a Deaf person is most likely to obtain a personal name sign: 1) in childhood (Deaf children of Deaf parents); 2) at a special school for Deaf (contemporaries); 3) in high school (Deaf co-students) (Meadow 1977: 240).

K. Vaik shows that although personal names can be changed, e.g. taking the spouse's surname when getting married, the main quality and requirement of a personal name is its constancy. Nicknames, being less constant than personal names, disappear or are replaced with new ones after their function is lost (Vaik 2006: 88).

There are different opinions with regard to changing the name sign in Deaf communities. Thus it is rather complicated for Chinese Deaf people to change their name sign and in most cases the personal name sign obtained at school will accompany a Deaf person throughout his or her life (Yau \& He 1990: 249250). Changing of name signs is not common in the Palestinian Deaf community either (Strauss-Samaneh 2001: 595). However, European (incl. Estonian) and American (U.S.) Deaf communities are more flexible and personal name signs can be changed more easily.

Problems arise with regard to changing a personal name sign that is unacceptable for a reference person. According to the general rule, personal name signs should not be offensive for a reference person. For example, in the Deaf community of New Zealand there have been cases where an unpleasant personal name sign was reportedly substituted with a new one, but in fact the old (unpleasant) name sign was still used (McKee \& McKee 2000: 26). Use of different name signs to denote the same person is also common among Estonian Deaf people. 
It is common to change a personal name sign in connection with a reference person's different stages of life. A new name sign indicates a change in the status of that person, for example, in the case of women the name sign may change when getting married. New name sign may also be introduced due to a new job. The change of a person's Deaf community (such as moving from Estonia to another country or vice versa) may also be a reason for getting a new personal name sign. The fact is that one person may have several name signs simultaneously, or according to an Estonian proverb: a good child has many names.

\section{METHODS OF FORMING PERSONAL NAME SIGNS}

Estonian Sign Language has four main categories of personal name signs (see Table 1) (Paales 2004: 202-205) and five categories of place name signs (Paales 2008: 17-18). In other national sign languages there are other methods for forming personal name signs besides those described in this article.

Firstly, arbitrary or initialised personal name signs are created on the basis of the written form of the reference person's official personal name. Such personal name signs contain the initials of the given name and/or surname, represented by hand shapes. For example, Andrus Ansip, current Prime Minister of the Republic of Estonia, is denoted by a two-part double-initialised name sign. The personal name sign is performed by using the A-hand shape corresponding to the initials of given name and surname (A+A) (see Fig. 1).

The second category is formed by descriptive (metonymic and metaphoric) name signs. The formation of a metonymic name sign is based on the reference person's appearance, behaviour, clothing, peculiarity, special characteristic, etc. Such descriptive name signs employ both the principle of metonymy using a part instead of the whole - and the principle behind metaphor, i.e. comparison. For example, the personal name sign of the politician Siim Kallas refers to his moustache (MISTER VUNTS [MISTER MOUSTACHE]) or, according to another explanation, to the dimple.

The third group consists of initialised descriptive personal name signs, where the hand shape, corresponding to the initial of the name, is associated with some attribute of the reference person, such as hairstyle. These personal name signs combine both initials and description. Several name sign researchers consider these name signs to be untraditional, hybrid, and a result of cultural contact between hearing people and Deaf people (Delaporte 2002: 214; Mindess 1990: 14-15). It is possible that one of the factors behind the formation of this mixed type comes from the opinion of hearing people that a "proper" name 
sign should be depictive or imitative: it blends the association of some exterior feature of the reference person with the initial of the reference person's given name or surname. E.g. in American Sign Language, the current President Barack Obama is referred to by using a personal name sign which combines both the initials of his surname and given name as well as indication to his logo dating back to his election campaign $(\mathrm{O}+\mathrm{B}+\log 0)$, which depicts the American flag and the initial of the surname Obama (see Fig. 2). The letter B (which is both the initial of his given name and the second letter in his surname) has undergone a morphological change and American B-hand shape denotes a flag in the name sign (Grigg-Langton 2009).
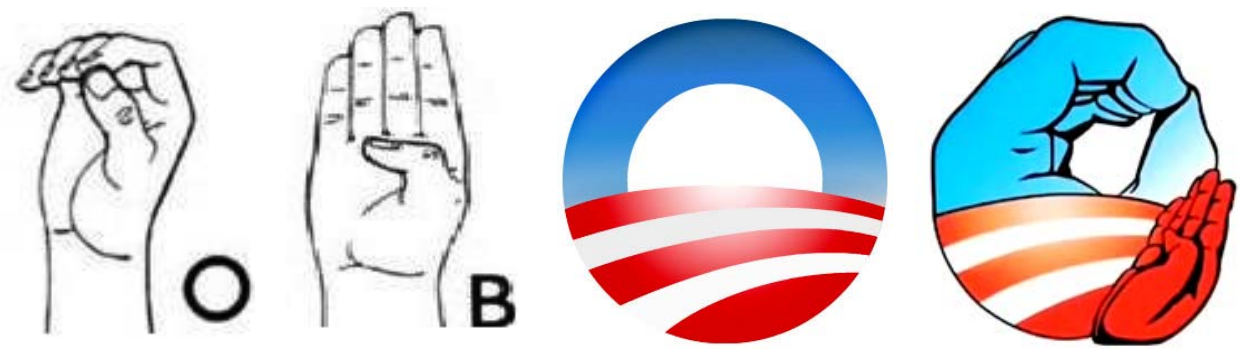

Figure 2. The sources of forming the name sign of Obama.

The fourth type of personal name signs includes loan/borrowed name signs and in this case the name sign is formed on the basis of the meaning of the reference person's official personal name. Such name signs are either total or partial homonyms in terms of written form of personal name, for example, in Russian Sign Language the personal name sign of Dmitri Medvedev, current President of Russia, is KARU [BEAR] (МЕДВЕД - медвед, 'bear' in Russian). The same name sign is used in Estonia as well and is probably a loan from the Russian Sign Language. For a Deaf person the meaning of the written form of a personal name speaks volumes - it gives a visual impulse, for which a suitable sign language translation is then searched.

\section{ATTRIBUTING PERSONAL NAME SIGNS TO HEARING PEOPLE}

Attributing personal name signs to hearing people is an interesting subject. Group-based classification of name signs is related to the concepts of Deaf and hearing person, which represent different communities, language and culture. Y. Delaporte has defined them as ethnonyms, names of different groups of people - Deaf and hearing people (Delaporte 2002: 52-55). 
Table 1. Categories and formation sources of Estonian personal name signs.

\begin{tabular}{|c|c|c|c|}
\hline $\begin{array}{c}\text { Categories of } \\
\text { personal name } \\
\text { signs }\end{array}$ & Types & \multicolumn{2}{|c|}{ Sources of forming personal name sign } \\
\hline \multirow{3}{*}{$\begin{array}{l}\text { arbitrary personal } \\
\text { name sign (A) }\end{array}$} & one-initial A1 & written personal name & initial of given name \\
\hline & two-initial A2 & written personal name & $\begin{array}{l}\text { initials of given name and } \\
\text { surname }\end{array}$ \\
\hline & finger spelled A3 & written personal name & given name \\
\hline \multirow{7}{*}{$\begin{array}{l}\text { descriptive personal } \\
\text { name sign (D) }\end{array}$} & \multirow[t]{4}{*}{ D1 } & \multirow[t]{4}{*}{ appearance } & hairstyle \\
\hline & & & face \\
\hline & & & other part of the body \\
\hline & & & $\begin{array}{l}\text { attributes (clothing, jewellery, } \\
\text { spectacles, etc.) }\end{array}$ \\
\hline & $\overline{\mathrm{D} 2}$ & $\begin{array}{l}\text { hobby, field of activity, } \\
\text { mode of conduct }\end{array}$ & $\begin{array}{l}\text { hobby } \\
\text { behaviour }\end{array}$ \\
\hline & D3 & $\begin{array}{l}\text { other feature of the } \\
\text { person }\end{array}$ & social status \\
\hline & D4 & unspecified feature & $\begin{array}{l}\text { forwarded or inherited personal } \\
\text { name sign } \\
\text { modification of conveyed personal } \\
\text { name sign }\end{array}$ \\
\hline $\begin{array}{l}\text { Initialised } \\
\text { descriptive personal } \\
\text { name sign }(\mathrm{AD})\end{array}$ & A1/D1 & $\begin{array}{l}\text { appearance and initial } \\
\text { of given name }\end{array}$ & initial of given name and hairstyle \\
\hline \multirow{3}{*}{$\begin{array}{l}\text { Loan/borrowed } \\
\text { personal name sign } \\
\text { (L) }\end{array}$} & L 1 total homonym & written personal name & surname \\
\hline & L 2 partial homonym & written personal name & surname \\
\hline & L 2 partial homonym & written personal name & given name \\
\hline
\end{tabular}

Considering that Deaf communities lived in relative isolation for a long time and did not have as much contact with the hearing community as today, there was no actual need to attribute name signs to hearing people. Anna Mindess also states that, e.g., in the American Deaf community it is a more recent tendency to attribute name signs to hearing people (Mindess 1990: 13-14). Nowadays, the attribution of personal name signs to hearing people has become common practice.

In this sense the acceptance of a hearing person or their involvement in the life of the community is irrelevant. Instead it is important that reference person is known in the Deaf community. In other words, people, who have been subject to discussion in the Deaf community, receive their own personal name sign (McKee \& McKee 2000: 21).

Deaf people began to give name signs to hearing people for various reasons and one of these was growing contact with the hearing society and the increase in popularity of sign languages. At first, name signs were attributed to 
people with close connections with Deaf people, but as the communication between the Deaf community and the dominant hearing society became more frequent, name signs were also given to people who were not so closely related to Deaf community.

Throughout history, teachers at the school for the Deaf have been treated as an exception, as they were attributed a name sign by the students. Personal name signs were also given to sign language interpreters who played a significant role in the Deaf community life. Nowadays it is common to attribute name signs to well-known public officials, and an interesting problem worth studying is whether and how Deaf people attribute name signs to their hearing children or relatives.

Deaf people consider a hearing person, who uses a self-created personal name sign to denote himself or herself, as culturally ignorant or as an intruder. This problem occurred along with the increasing popularity of studying sign language. According to the observations made with regard to the American Deaf community, a personal name sign becomes a source of humour when incompetently used by a hearing person, who lacks knowledge of Deaf heritage or has insufficient language proficiency. Such a hearing person may become a laughing-stock (Rutherford 1993: 126). Deaf people themselves, however, may also manipulate name signs in order to make a joke or to satirise.

\section{A SELECTION OF NAME SIGNS ATTRIBUTED TO HEARING PEOPLE}

Below is given a selection of personal name signs attributed to hearing people, starting from those having closer connections with the Deaf community (e.g. teachers, sign language interpreters, hearing children of Deaf parents) and moving on to the name signs of public figures (e.g. public officials, athletes, singers, etc.). Last but not least, the author discusses religious personal name signs. The examples are taken mostly from Estonian Sign Language, but also from other sign languages.

\section{People related to the Deaf community}

Teachers of Deaf schools. Conversations with older generations of Deaf people revealed descriptive personal name signs of two people who have played a significant role in the educational history of the Estonian Deaf community. The name sign attributed to Ernst Sokolovski (1833-1899), Lutheran pastor and founder of the first school for Deaf in Estonia, refers to his sideburns (see 
Photo 1). E. Sokolovski taught Deaf children by applying the German method.10 Transfer of the School for Deaf from Vändra to Porkuni in 1924-1925 was organised by the school manager and renowned teacher of the Deaf, Volmer Univer (1865-1941), whose name sign refers to chin whiskers (see Photo 2). These are most likely among the oldest personal name signs in Estonian Sign Language attributed to hearing people and preserved to this day. The Finnish researcher of name signs, Päivi Rainò, points out that only a few name signs survive after the death of the reference person (Rainò 2005: 7).

Similar examples, of personal name signs for hearing teachers of Deaf people, are also found in other national sign languages. For instance, CharlesMichel de l'Épée, a Frenchman, who in 1755 founded the first public school for the Deaf in the world, has a two-part descriptive name sign. The first part of the name sign refers to a formerly worn clerical collar, and the second part is a translation from the French word épée (SWORD) (Supalla 1992: 23). The Reverend Thomas Hopkins Gallaudet (1787-1851) was a well-known hearing American, who established a school for the Deaf in Hartford, U.S. in cooperation with a French teacher, Laurent Clerc (Deaf). The personal name sign of Gallaudet, which also denotes Gallaudet University for the Deaf in Washington D.C., refers to his spectacles. The name sign of Gallaudet has obviously been attributed by the French Deaf community, as he stayed in Paris for a long time, to master the so-called French method ${ }^{11}$ (Supalla 1992: 25-26).

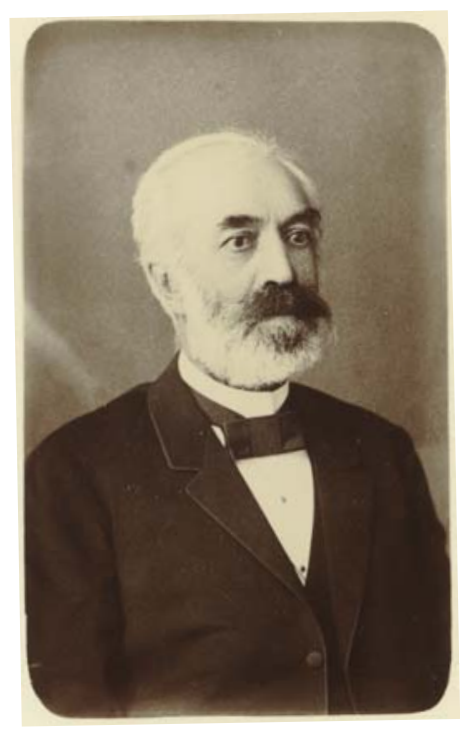

Photo 1. Ernst Sokolovski (EKLA A-37: 5051)

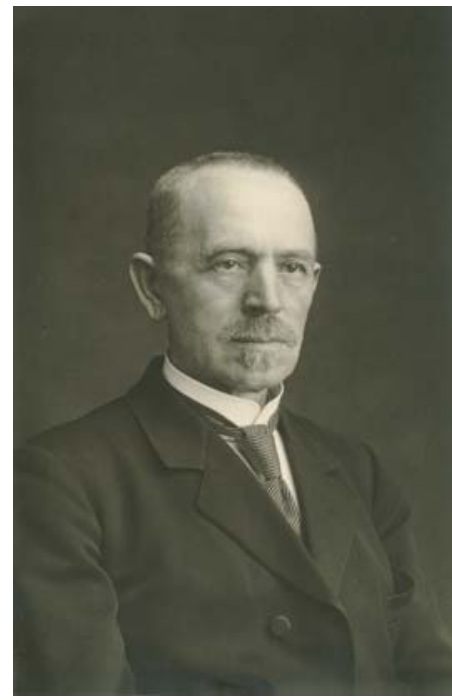

Photo 2. Volmer Univer (EKLA A-1: 1762) 
Personal name signs, attributed to the teachers who worked at Porkuni School for the Deaf during the Soviet period, are mostly descriptive, referring to various external characteristics of the reference person ETTEULATUV LÕUG [LANTERN-JAWED], LÕUALOTT [DOUBLE CHIN], HÕRE JUUKSETUTT LAUBAL [THIN WISP OF HAIR ON THE FOREHEAD], RAHULIK [CALM], SALE FIGUUR [SLIM], LAIAPUUSALINE [WIDE HIPS]). There are also borrowed personal name signs, such as SAAR [ISLE] (abbreviated from surname Ojasaar). The name signs of teachers are often clearly derogatory (cf. also McKee \& McKee 2000: 21). This may be due to seeing the teachers as enactors of the power of hearing society, as they were the ones who provided education by using the oral method, which was arduous for Deaf people.

The name signs of teachers of the school for the Deaf have been subject to linguistic games. For instance, the students of Porkuni School modified the name sign of the reference person according to reference person's behaviour. In a normal situation the name sign RAHU(LIK) [CALM] was used, which referred to generally composed behaviour and the level-headed personality of the reference person. But when that teacher was upset, the name sign RAHU(LIK) [CALM] was replaced with the name sign KONGUS NINA [HOOKNOSED]. A teacher's name sign was also altered if the students did not want the teacher to know that he or she was being talked about. Students often had to modify a teacher's name sign after he or she understood sign language and recognised his or her name sign.

Sign language interpreters. Sign language interpreters represent another group of people who are closely related to the Deaf community and are always given personal name signs. Two name signs were simultaneously used in the Deaf community for Helvi Tõnurist (1942-2004), a renowned interpreter, trainer of interpreters, founder and the first chairwoman of the Association of Estonian Sign Language Interpreters. Both personal name signs were loans - the first one was based on her maiden name Lepp (personal name sign LEPP [ALDER]) and the second on rist, the final component of her surname which is a compound word Tõnurist (name sign RIST [CROSS]).

Loan name signs have also been attributed to the experienced sign language interpreters Liivi Hollman and Ulvi Saks, who have interpreted the news for the Deaf and hearing impaired people on Estonian Television for years. The first one of them carries a personal name sign LIIV [SAND], derived from the word liiv ('sand') which bears resemblance to her given name Liivi, and the second one has name sign SAKSA [GERMAN], derived from the word Saksamaa ('Germany') (or sakslane ('German')) which bears resemblance to her surname Saks. Both name signs are partial homonyms with regard to their official names. 
An interpreter with the surname Kroon bears the personal name sign KROON [CROWN], which is a total homonym. The name sign with partial homonym KUKK [ROOSTER] has been attributed to a sign language interpreter whose surname is Kukkela. The sign language interpreter Helle Sass bears a name sign, where similar to the previous example, the sign name has been created on the basis of the resemblance of her surname to another word (Sass-sassis [SHAGGY]).

Deaf culture and sign language researchers. Name signs are also given to the researchers of Deaf culture and sign language who communicate with the Deaf community. The name sign of the pioneer of linguistic study of sign languages, American Sign Language researcher William C. Stokoe (1919-2000) is performed with open and bent fingers like the American B-hand shape (see Fig. 2). The hand with palm facing downwards is placed on the top of one's head, so that the bent fingers touch the forehead. This name sign refers to Stokoe's exceptionally thick hair which he wore in a bowl-like, almost medieval style (Maher 2002: 133). The personal name sign of Vahur Laiapea, a researcher of Estonian Sign Language, indicates the position of the reference person's ears. French ethnologist Yves Delaporte has a name sign CELUI QUI PREND DES NOTES [THE ONE WHO TAKES NOTES] (see Fig. 3). ${ }^{12}$ This name sign refers to the reference person's habit of carrying along a small notebook for making notes. The Finnish name sign researcher Päivi Rainò (Pimiä) $)^{13}$ has two loan name signs associated with the translation equivalents of her given name and surname in Finnish Sign Language. The first personal name sign is performed with two hands " PÄIVÄ (Päivi) + YÖ/PIMEÄ (Pimiä) ('day + night/dark'), the second one with one hand - PIMEÄ ('dark') (Rainò 2004: 46-47). A name sign SPORT of a German Deaf community researcher, Anne Uhlig, indicates her athletic lifestyle (Fig. 4). ${ }^{14}$ According to her, she was given this name sign by a Deaf person who frequently saw her coming to work by bicycle. The name sign of the author incorporates both the initial of her given name - L-hand shape - and former hairstyle (see Fig. 5).

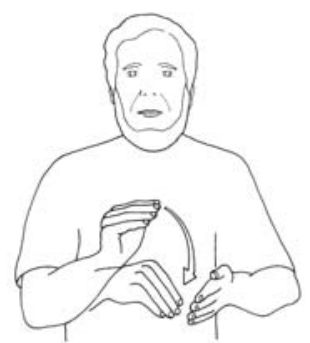

Figure 3. THE ONE WHO TAKES NOTES

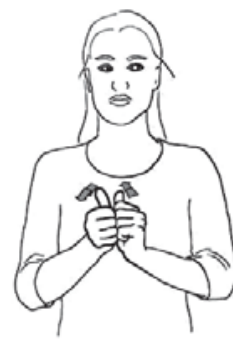

Figure 4. SPORT

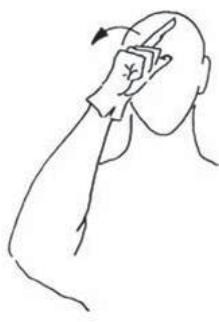

Figure 5. $L+K A A R J A S$ TUKK $[L+C U R V E D$ FORELOCK] 
Hearing children of Deaf parents. New Zealand name sign researchers believe that as a rule, local Deaf parents do not attribute name signs to their hearing children, although the latter take part in community life. They may get their name sign after obtaining a significant social role in the community. One of the reasons seems to be the fact that hearing children tend to define themselves as members of the hearing society. David and Rachel L. McKee argue that even more important may be the fact that they do not enter the Deaf peer group (i.e. they do not learn at the school for Deaf), where students communicate in sign language and attribute each other personal name signs (McKee \& McKee 2000: 21).

According to A. Mindess, American Deaf parents used not to give name signs to their hearing children, although they were inherent signers and grew up by communicating with their parents and Deaf friends (Mindess 1990: 13). While studying the origin of Finnish name signs (home, school, etc.), P. Rainò observed that over the decades there has been an increase in giving name signs to hearing children (see Rainò 2004: 83).

Attribution of name signs to hearing children by their Deaf parents has not been studied in Estonia, but based on initial observations we may say that it does occur to some extent. In a signing family the hearing children have been granted their name sign at birth; let us, for example, view the name sign based on surname Toom. The name sign TOOM [DOME] is extended to the entire family, and the signing is accompanied with the mouth pattern of the surname. The name sign is a two-handed sign performed as an upside down E-hand shape. The passive hand is stationary, and the dominant hand moves upwards above the passive hand. Estonian Sign Language contains other lexical signs, where the first part is signed in the same way as the aforementioned name sign (e.g. TOOM+KIRIK [TOOM+CHURCH] (Dome church), place name sign TOOM[PEA] (TOOM[HEAD]) (Cathedral Hill - a limestone hill in the central part of the city of Tallinn, the capital of Estonia). The reference person interprets this personal name sign as a visualisation of the double vocal 'oo', which takes the form of a pipe or a cylinder when signed. Family members were distinguished as follows: TOOM+MEES [TOOM+MAN] (father), TOOM+NAINE [TOOM+WOMAN] (mother), TOOM+TÜTAR [TOOM+DAUGHTER] and TOOM+POEG [TOOM+SON]. The daughter has obtained a significant role as a sign language interpreter and active participant in the life of the Deaf community for decades and therefore her name sign is deeply rooted and has remained in constant use, unaltered. ${ }^{15}$ The son has less intense contact with the Deaf community, but despite that his personal name sign TOOM+POEG $[\mathrm{TOOM}+\mathrm{SON}]$ is still used. 
A similar example has been described in New Zealand Sign Language (McKee \& McKee 2000: 31). P. Rainò refers to an analogous case in a Finnish Deaf family, where a hearing child was given her own personal name sign outside the family. At home she was denoted by her parents by the sign TYTTÖ [DAUGHTER] and in the local Deaf community she was denoted as NIEMELÄ-TYTTÖ [NIEMELÄ-DAUGHTER] whereas the Niemelä-sign was her father's personal name sign (Rainò 2004: 81).

\section{Public figures}

Estonian public officials. The Deaf community has attributed its own name signs to heads of state and politicians, however, personal name signs have also been given to other public figures, such as athletes, writers, and even singers, although the latter are not very popular in Deaf culture.

The personal name sign KIKILIPS [BOW-TIE] of Toomas-Hendrik Ilves, current President of the Republic of Estonia, refers to his passion for wearing a bow-tie (see Fig. 6; EFA I 47, 116). The personal name sign of Lennart Meri, the first President of Estonia after restoration of independence is a loan sign (MERI [SEA]), derived from the meaning of his surname (see Fig. 7; EFA I 47, 116). The name sign of former President Arnold Rüütel (ARNOLD AURAHA [ARNOLD BADGE OF HONOUR]) refers to badges of honour worn on the chest (see Fig. 8; Püve 2002). The name sign of Siiri Oviir, a member of the European Parliament, is associated with her spectacles (PROUA PRILL [MISSIS SPECTACLES]). The personal name sign of politician Mart Laar (MART HABE [MART BEARD]) indicates his sideburns (see Fig. 9; Püve 2002). The name sign of Ivi Eenmaa, Estonian politician and librarianship-related figure, is associated with her beloved accessory, a hat - PROUA KÜBAR [MISSIS HAT] (Püve 2002). The personal name sign of Laine Jänes, former Minister of Culture (JÄNES [RABBIT]) is the translation equivalent to her surname (see Fig. 10).

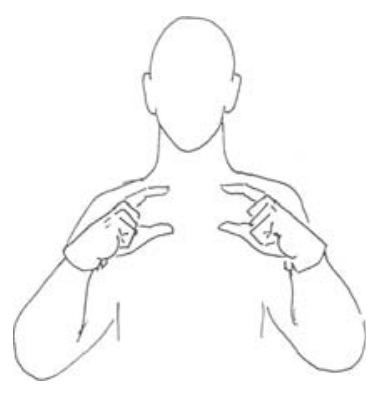

Figure 6. KIKILIPS [BOW-TIE]

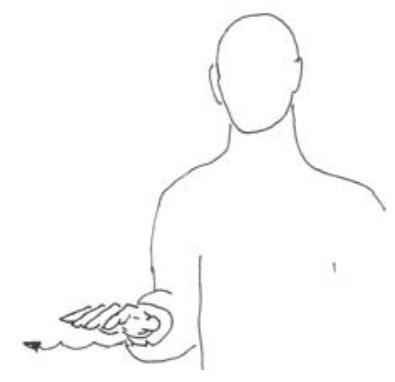

Figure 7. MERI [SEA] 


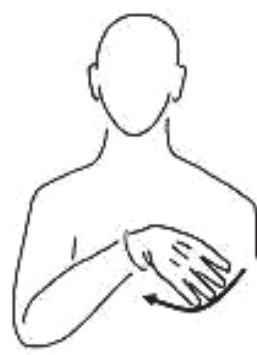

Figure 8. $A R N O L D$ AURAHA [ARNOLD BADGE OF HONOUR]

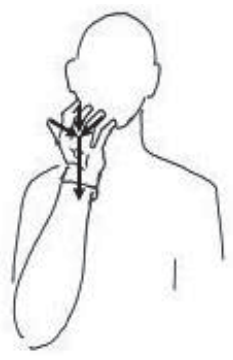

Figure 9. MART HABE [MART BEARD]

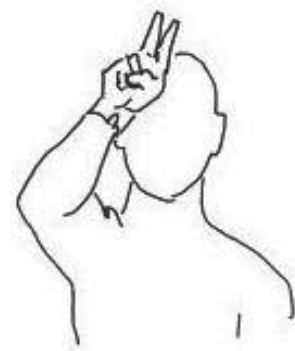

Figure 10. JÄNES [RABBIT]

Finnish public officials. In Finnish Sign Language, the name sign of Tarja Halonen, current President of Finland, refers to the big nose of the reference person. The name sign of former President Martti Ahtisaari indicates his overweight state and his resulting way of walking. The personal name sign of politician Paavo Lipponen refers to his swivel-eyed look (Venemäki 2005).

Russian heads of state. The heads of state and politicians of former Soviet Union have been denoted in Estonian Sign Language (and most likely in Russian Sign Language as well) by descriptive metonymic personal name signs, which refer to the physical features of the reference person. The personal name sign of Vladimir Lenin indicates his chin whiskers (TUTTHABE [TUFT BEARD]), Joseph Stalin's refers to his luxuriant moustache and the personal name sign of Nikita Khrushchev is associated with the wart on his nose (PUNNNINA [WART NOSE]). Leonid Brezhnev's name sign indicates his thick eyebrows (HÄRRA KOHEVKULM [MISTER RUFFLED BROW]) (see Fig. 11; EFA I 47, 115), and the personal name sign of Mikhail Gorbachev is associated with the striking pigmentation on the top of his head - PIGMENDIPEA [PIGMENT HEAD] (see Fig. 12). With regard to Boris Yeltsin, the first President of the Russian Federation, there are two known name signs in the Estonian Sign

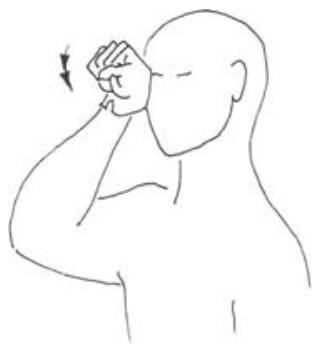

Figure 11. KOHEVKULM [RUFFLED BROW]

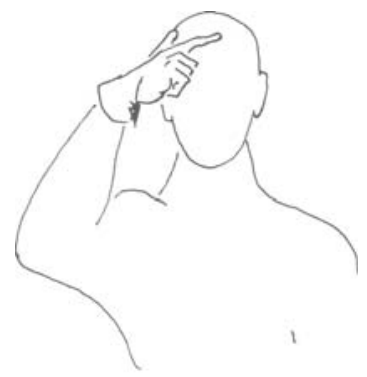

Figure 12. PIGMENDIPEA [PIGMENT HEAD] 


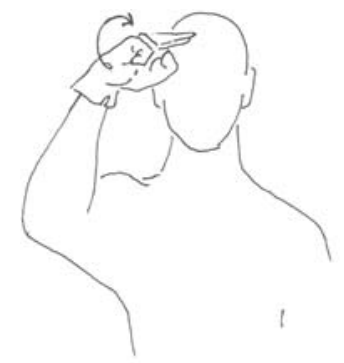

Figure 13. PAKSTUKK [THICK FORELOCK]

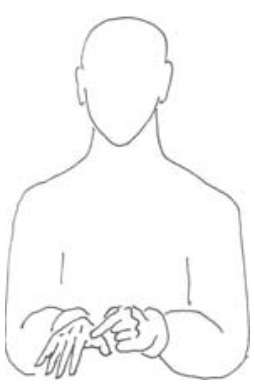

Figure 14. $P U U D U V$ PÖIAL [MISSING THUMB]

Language - the first one, the so-called official version, refers to his ruffled hairstyle (HÄRRA PAKSTUKK [MISTER THICK FORELOCK]) (see Fig. 13; EFA I 47, 115), and the second, more familiar one indicates his missing thumb (see Fig. 14; EFA I 47, 115); in Russian Sign Language another name sign for Yeltsin has been reported, indicating the red nose of the alcohol-loving president.

One of the name signs attributed to Vladimir Putin refers to his nose (TERAVNINA [POINTY NOSE] ${ }^{16}$ or, alternatively, his surname is fingerspelled $^{17}$ (P-U-T-I-N). In Russian Sign Language, Emperor Peter I has been attributed a special name sign, consisting of two parts: the first sign indicates his moustache and the second refers to number I (ESIMENE VUNTS [THE FIRST MOUSTACHE]).18

German heads of state. The name sign of Adolf Hitler in Estonian Sign Language consists of two parts: the first sign refers to the moustache under his nose and the second to the Nazi salute that involved a certain gesture. Chancellor Angela Merkel has a sign, in German Sign Language, referring to the down-pointing corners of her mouth; the personal name sign of HansDietrich Genscher, the former German Minister of Foreign Affairs, indicates

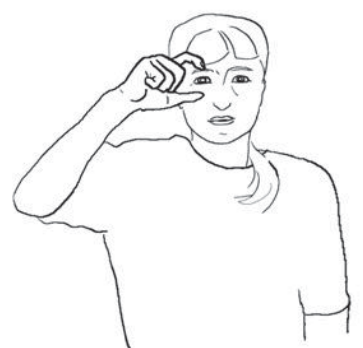

Figure 15. SPECTACLES

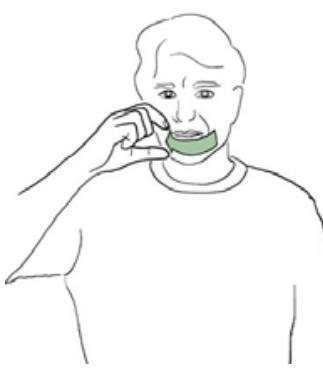

Figure 16. BIG TEETH/ GRIN 
his big ears (Colmenares 2005). The name sign of Erich Honecker, the last head of state of East-Germany (see Fig. 15) apparently refers to his spectacles, and that of Egon Krenz, another politician of former East-Germany (see Fig. $16)$, is associated with his big teeth and grin. ${ }^{19}$

France. François Mitterrand, who was elected the President of France twice, is attributed several personal name signs in French Sign Language (Delaporte 2002: 223). His initial personal name sign, performed by the French M-hand shape, derives from the first letter of his surname. In a caricatured version, both M-hand shape and place of sign formation are modified - the personal name sign is performed in front of the mouth (see Fig. $17^{20}$ ). This name sign refers to Mitterand's bad dental occlusion and to his vampire-like incisors MITTERRAND LE VAMPIRE [MITTERRAND-VAMPIRE]). ${ }^{21}$ Another modification of the aforementioned name sign results in a new version MITTERRAND LE VAMPIRE AUX DENTS ÉLIMÉES [MITTERRAND - A VAMPIRE WITH TEETH REMOVED] (see Fig. 18; Delaporte 2002: 223). This name sign refers to the election campaign at the time when F. Mitterrand was running as a candidate for the third term of office and had his incisors removed to create a more pleasant impression for his constituents (Tiersky 2003: 298).

The name sign of Nicolas Sarkozy, current President of France, refers to his pointy ears (OREILLES POINTUES). ${ }^{22}$ The personal name sign of Jacques Chirac, former President of France, indicates his pointy nose (NEZ POINTU), whereas the name sign of French politician Michel Rocard implies bags under his eyes (POCHES SOUS LES YEUX) (Delaporte 2002: 206-207). Speaking of historical figures, Estonian Sign Language contains a name sign for Napoleon, indicating the typical pose of the French emperor (with his hand slipped into his coat).

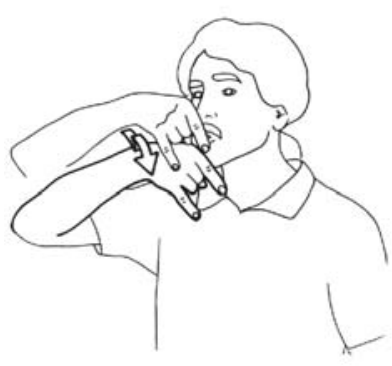

Figure 17. MITTERRANDVAMPIRE

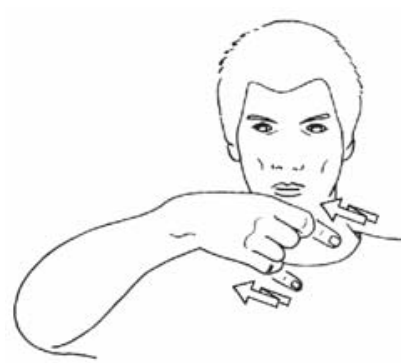

Figure 18. MITTERRANDVAMPIRE WITH TEETH REMOVED 
Presidents of the United States. American Deaf people have come up with personal name signs for their former heads of state: Richard Nixon, Jimmy Carter, Gerald Ford, and Ronald Reagan (Carmel 1996: 199). It is remarkable how personal name signs have been altered to correspond to the changes that took place in the lives of these public officials, which reflects the linguistic humour of Deaf people. ${ }^{23}$ In case of more popular people, the American Deaf community has used several different personal name signs.

For example, formerly the personal name sign of President Nixon was performed by the American N-hand shape next to the nose and it referred to Nixon's long nose bridge. After the Watergate scandal his name sign was altered - now the same hand shape was moved across the chin, referring to a liar. According to the interpretation of Edward S. Klima and Ursula Bellugi the English equivalent of this name sign could be (in terms of its effect, not form) $M r$. Trixon, which combines his name with word tricks. The personal name sign of Carter was performed with two hands, as the C-hand shape imitated his famous smile (GRIN) (Klima \& Bellugi 1979: 331). When signing the personal name sign of President Ford, the F-hand shape was formed on the forehead, which signified the head bandage that he wore after an unfortunate fall.

One of the personal name signs of Ronald Reagan was performed by using an R-hand shape, while moving the hand over the head, indicating the imposing hairstyle of the president. The name sign was changed after Reagan was wounded in an attack on him: the tip of R-hand shape pointed to the place of wound (Carmel 1996: 199). The name sign of Bill Clinton underwent a similar change (American C-hand shape) in connection with the so-called Lewinsky affair (Püve 2002).

Leaders of other countries. The Estonian name sign of Tony Blair, former Prime Minister of Great Britain, indicates the distant position of his ears from his head. In Chinese Sign Language, the name sign of the Chinese communist leader Mao Zedong refers to the wart on his chin (Delaporte 2002: 206). Gloria Macapagal-Arroyo, the President of the Republic of Philippines, has a sign referring to a mole on her left cheek while that of former President Joseph Estrada refers to his permanent attribute - an armband. The name sign of President Fidel Ramos is associated with his weakness for cigars (What's in Sign Name?). Robert Muldoon, one of the former Prime Ministers of New Zealand, had a descriptive personal name sign, indicating his peculiar left cheekbone while former Prime Minister Jenny Shipley had an initialised loan name sign J+SHIP , derived from the initial of her given name and the meaning of her surname (McKee, McKee 2000: 21). In German Sign Language the name sign of Osama bin Laden, the notorious international terrorist and leader of 
the terrorist network Al-Qaeda, is associated with his long beard and is performed by using the German S-hand shape, moving downward from the chin, accompanied by an "evil" facial expression (Colmenares 2005).

As seen from the examples above, a name sign is a multi-layered object of linguistic play with merged meaning and form. Play with name signs combines content and form into one single element whereby unexpected meanings are compressed in a minimum sign form. This can be achieved in many ways. Sometimes it is done by changing internal parameters of the $\operatorname{sign}^{24}$, sometimes by performing two different signs simultaneously with both hands, and in other times the signs are combined or one sign is merged with the other (Klima \& Bellugi 1979: 320).

Do the prominent figures of the majority society have any awareness of and interest in how they are denoted in a minority language? In the context of the cultural standards of the hearing society, most descriptive personal name signs are politically incorrect. Without knowing the origin and etymology of their name signs, the hearing people may falsely interpret their name sign as, for instance, Samak Sundaravej, the Prime Minister of Thailand, was upset by the name sign attributed to him - in the local sign language the prime minister is denoted by grabbing one's nose with two fingers, referring to his particularly big nose. The name sign is generally known among local Deaf community members and local signers understand instantly whom they are talking about. As a Member of Parliament, Sundaravej was not frequently mentioned in sign language news. The only reasons for him to be noticed were his corruption scandals. As soon as he became Prime Minister, he suddenly became a daily topic and the sign language interpreters are forced to grab their nose about 300 times a day. In Sundaravej's opinion this name sign - grabbing one's nose - depicts him as a person with double standards and indicates poor hygiene (Thailand Prime Minister upset by sign language).

Athletes, singers, actors. Sport is a significant sphere in Deaf communities and a popular subject of discussion. As for hearing athletes, Estonian decathlete and Olympic winner Erki Nool has been attributed his own personal name sign, which is associated either with his main event pole-vault (TEIVASHÜPE [POLE-VAULT]) or with the meaning of his surname (NOOL [ARROW]). The name sign of Estonian weight-lifter Jaan Talts (KANGI-JAAN [BARBELL JAAN]) represents a caricature of weight-lifting (Püve 2002).

In Finnish Sign Language, the personal name sign of former well-known ski jumper Matti Nykänen is still SKI-JUMP, although he left the sport a long time ago. The Finnish name sign of footballer David Beckham refers to his former punk-style hairdo (Venemäki 2005). The personal name sign of legen- 
dary German racing driver Michael Schumacher, in German Sign Language, is a translation equivalent of his surname (Schumacher - 'shoemaker'). The name sign imitates knocking on shoes, and in order to distinguish the reference person from his younger brother Ralf, who is also engaged in motor racing, this name sign is accompanied by an articulated mouth pattern 'Michael' (Colmenares 2005).

In Estonian Sign Language, the film director and actor Charlie Chaplin is denoted by two-part name sign: the first refers to moustache and the second part to his signature walk (VURRUD+PARDIKÕNNAK [MOUSTACHE+DUCK WALK]). Even some singers have found their place in the sign language name system. Thus, the name sign of the king of rock'n'roll, Elvis Presley, in Finnish Sign Language is derived from his extravagant hairstyle. Michael Jackson's name sign indicates a lock of hair falling on his face (Venemäki 2005). In Russian Sign Language, the name sign of Alla Pugacheva refers to the bushy hair of the singer.

In German Sign Language the name sign attributed to Madonna imitates the corset with conical breasts made for her by French fashion designer JeanPaul Gaultier, and Marilyn Monroe's name sign refers to a mole near her lips. The name sign of popular German folk singer Heino is signed with two hands: one hand imitates holding a microphone and the other hand imitates reference person's spectacles with thick glasses. Supermodel Claudia Schiffer's name sign is performed with the German C-hand shape, and the movement imitates shaking a perfume bottle (Colmenares 2005).

\section{RELIGIOUS PERSONAL NAME SIGNS}

Name signs of religious figures, as a specific name group in local sign languages, represent an interesting research subject, but according to the author's knowledge it has not yet been studied.

Christianity. In the course of translating biblical texts the personal names occurring in the Bible have been given translation equivalents in the context of local sign languages. ${ }^{25}$ There are different records of personal name signs of biblical figures (e.g. see Vuorijärvi 2008: 4). For instance, in Estonian Sign Language the personal name sign of Abraham ('Aabraham' in Estonian) from the Old Testament (TAKISTATUD NOAHOOP [BLOCKED STABBING]) refers to the story of the sacrifice of Isaac ('Iisak' in Estonian) in Chapter 22 of the First Book of Moses (Fig. 19). The personal name sign of Moses ('Mooses' in Estonian) indicates the reference person's big beard (HABE [BEARD]), shown 
on several works of art depicting the leader of the people of Israel. The name sign attributed to Aaron, the brother of Moses, is KEPP [ROD], which refers to his rod endowed with miraculous power (The Second Book of Moses, 7:9), and the well-known Old Testament prophet Elijah ('Eelija' in Estonian) (TAEVASSE SÕITMA [ASCEND TO HEAVEN], Fig. 20) has one indicating the ascension of the prophet to heaven in a whirlwind and chariots of fire (The Second Book of Kings, 2:11).

The personal name sign of Jesus Christ ('Jeesus Kristus' in Estonian) signed with two hands (Fig. 21) refers to the crucifixion both in Estonian and other (e.g. Finnish, French) sign languages (NAELAHAAVAD KÄTES [NAIL WOUNDS IN HANDS]) (cf. Delaporte 2002: 313; Suvi). Apostle Thomas ('Toomas' in Estonian) has a sign (OMA SILM ON KUNINGAS [SEEING IS BELIEVING]) referring to a story where the follower of Jesus wishes to see the nail wounds of his teacher, before believing his resurrection from the dead (John 20:24-29). The name sign of King Herod ('Heroodes' in Estonian) contains reference to the initial $\mathrm{H}$ and royal headwear (Figs. 1, 27). The name sign for Andrew ('Andreas' in Estonian), the brother of Apostle Peter, contains an A-hand shape (Figs. 1, 23). As a reference to a brotherly relationship this name sign is performed in the same region of the body as the personal name sign of Peter. The name sign of Bartholomew ('Bartolomeus' in Estonian), the follower of Jesus, contains the initial of his given name B (see Figs. 1, 24), and that of Philip ('Filippus' in Estonian), another follower of Christ, his initial, F (see Figs. 1, 25). Signing of name signs is accompanied by articulation of phonetic names.

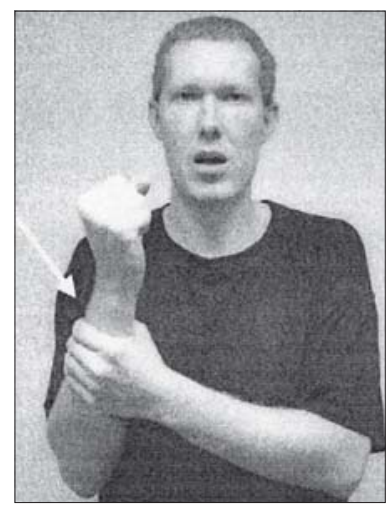

Figure 19. TAKISTATUD NOAHOOP [BLOCKED STABBING]

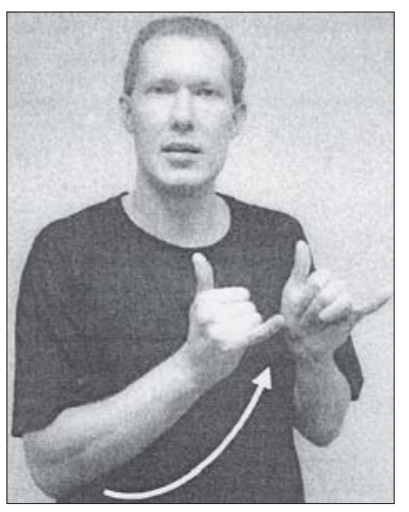

Figure 20. TAEVASSE SÕITMA [ASCEND TO HEAVEN] 


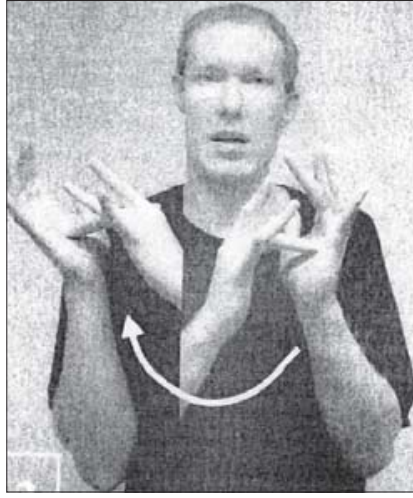

Figure 21. NAELAHAAVAD KÄTES [NAIL WOUNDS IN HANDS]

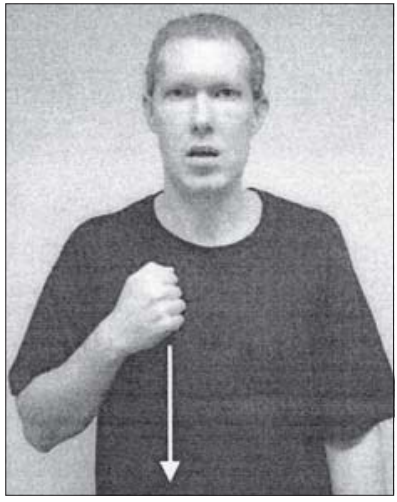

Figure 23. A (Andreas) [Andrew]

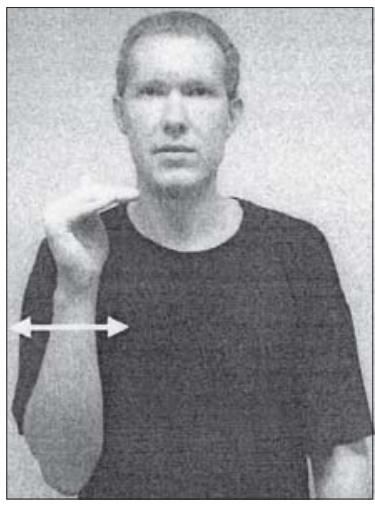

Figure 25. $F$ (Filippus) [Philip]

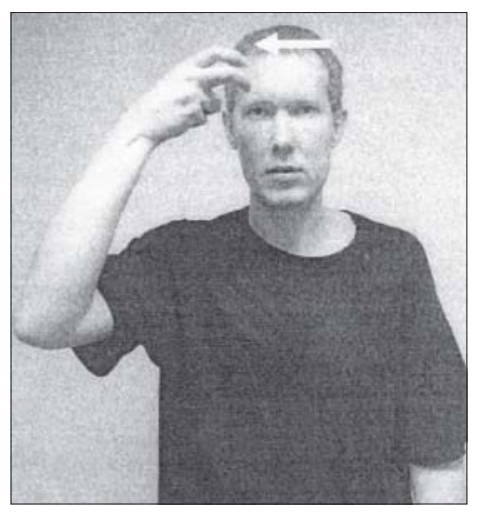

Figure 22. $H$ (Heroodes) [H (Herod)]

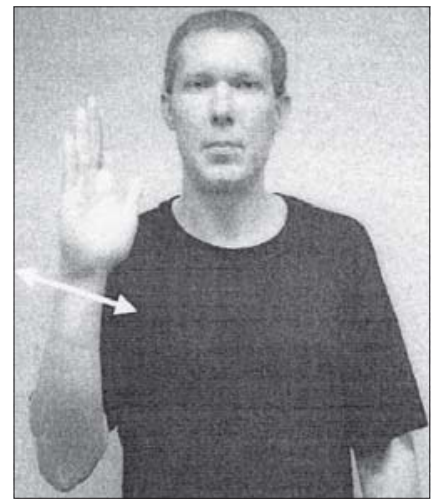

Figure 24. B (Bartolomeus) [Bartholomew] 
Buddhism. Buddha Śākyamuni, the founder of Buddhism, and also Buddhism itself are denoted by the O-hand shape (see Fig. 1). The two-handed personal name sign in the Estonian Sign Language refers to the particular position of hands when meditating.

\section{SUMMARY}

For centuries Deaf communities have been relatively isolated. Now, signing people have integrated or are about to integrate with the majority society in many countries. Increased attribution of name signs to those outside the community is also a result of cultural contact.

On the one hand, naming traditions are something generally common to Deaf communities, but on the other hand name signs are considered to be a multi-layered and versatile manifestation both linguistically, socially and with regard to heritage.

Personal name signs are used for denoting a third person in a conversation, not as call signs. In an onomastic context the name signs denoting people are considered proper names; they have features common to nicknames, as well as segments of official personal names, which are manifested in the context of communication within the Deaf community.

The factors that affect the formation of name signs include spoken language and the dominant hearing culture. Written forms of given names and surnames provide one possible source for name sign formation. The name system of the Deaf is also affected by cultural understanding of sign language by hearing people. According to the assumption voiced by researchers, hearing people think that every sign is supposed to depict/imitate something, and this understanding has forced Deaf people to create hybrid, mixed type personal name signs which combine the initial of a given name and/or surname and reference to a person's personal features. On the other hand, it is believed that these "hearing-based" personal name signs are created purposefully, in order to signify the hearing people as outsiders from the Deaf community. Today, such a practice of forming the above-mentioned name signs is prevalent: personal name signs of these mixed types are given to both Deaf and hearing people.

Various groups of the hearing society are represented in the name heritage of Deaf communities. At first, personal name signs were attributed to people closely related to the community, mainly teachers, sign language interpreters, and hearing family members. Nowadays, name signs are also given to people who are talked about in the community or who are important for some other 
reason, whereas direct relation and contact of such a person with the Deaf community is irrelevant. Personal name signs are given to heads of state, politicians, athletes, actors, and representatives of other professions. Name systems of Deaf people also include historical and religious figures. More popular figures have more than one name sign.

Personal name signs of hearing people are created and developed in the context of a local national Deaf community and sign language. Name signs given to internationally known figures vary by communities, but some personal name signs may transfer from one sign language to another. From the name formation aspect, in general, there is no difference between personal name signs of the Deaf and hearing people.

Descriptive name signs contain coded information about a reference person's life, appearance, habits, character and other typical features. Changes in the circumstances relating to this person are also reflected in personal name signs. Likewise, name signs may be subject to linguistic games.

There are certain socio-linguistic restrictions to be applied when attributing personal name signs. According to the general rule, name signs should not be offensive for the reference person. Members of the dominant hearing society see descriptive personal name signs as mocking, but in fact that judgmental connotation is not primary - description serves first and foremost the purpose of identification.

Personal name signs of hearing people represent an interesting lexical group in terms of cultural history and traditions. As the keeper of the signing community memory, reflection of attitudes and beliefs, name signs embody contacts, tensions and the different world view of the two communities. In the context of onomastics name signs, as a name category, give rise to theoretical discussions about their essence and classification.

\section{APPENDIX}

\section{Index of Name Signs}

Aabraham (Estonian SL)

Aaron (Estonian SL)

Ahtisaari, Martti (Finnish SL)

Andreas (Estonian SL)

Ansip, Andrus (Estonian SL)

Bartolomeus (Estonian SL)

Beckham, David (Finnish SL)
Bonaparte, Napoleon (Estonian SL)

Bin Laden, Osama (German SL)

Blair, Tony (Estonian SL)

Brezhnev, Leonid (Estonian SL)

Buddha (Estonian SL)

Carter, Jimmy (American SL)

Chaplin, Charlie (Estonian SL) 
Chirac, Jacques (French SL)

Clinton, Bill (Estonian SL)

Delaporte, Yves (French SL)

Epée, Abbé Charles-Michel (de l')

(French SL)

Eelija (Estonian SL)

Eenmaa, Ivi (Estonian SL)

Estrada, Joseph (Philippine SL)

Filippus (Estonian SL)

Ford, Gerald (American SL)

Gallaudet, Thomas Hopkins

(American SL)

Genscher, Hans-Dietrich (German SL)

Gorbachev, Mikhail (Estonian SL)

Halonen, Tarja (Finnish SL)

Heino (German SL)

Heroodes (Estonian SL)

Hitler, Adolf (Estonian SL)

Hollman, Liivi (Estonian SL)

Honecker, Erich (German SL)

Ilves, Toomas-Hendrik (Estonian SL)

Jackson, Michael (Finnish SL)

Jeesus Kristus

(Estonian/Finnish/French SL)

Jänes, Laine (Estonian SL)

Kallas, Siim (Estonian SL)

Krenz, Egon (German SL)

Kroon, Monika (Estonian SL)

Khrushchev, Nikita (Estonian SL)

Kukkela, Tiiu (Estonian SL)

Laar, Mart (Estonian SL)

Laiapea, Vahur (Estonian SL)

Lenin, Vladimir (Estonian SL)

Lipponen, Paavo (Finnish SL)

Macapagal-Arroyo, Gloria (Philippine SL)

Madonna (German SL)

Mao Zedong (Chinese SL)

Medvedev, Dmitri (Estonian/Russian SL)

Meri, Lennart (Estonian SL)
Merkel, Angela (German SL)

Mitterrand, François (French SL)

Monroe, Marilyn (German SL)

Mooses (Estonian SL)

Muldoon, Robert (New Zealand SL)

Nestor, Eiki (Estonian SL)

Nikolai II (Japanese SL)

Nixon, Richard (American SL)

Nool, Erki (Estonian SL)

Nykänen, Matti (Finnish SL)

Obama, Barack (American SL)

Oviir, Siiri (Estonian SL)

Paabo (Toom), Regina (Estonian SL)

Paales, Liina (Estonian SL)

Peeter I (Estonian SL)

Presley, Elvis (Finnish SL)

Pugacheva, Alla (Russian SL)

Putin, Vladimir (Estonian SL)

Rainò (Pimiä), Päivi (Finnish SL)

Ramos, Fidel (Philippine SL)

Reagan, Ronald (American SL)

Rocard, Michel (French SL)

Rü̈̈tel, Arnold (Estonian SL)

Saks, Ulvi (Estonian SL)

Sarkozy, Nicolas (French SL)

Sass, Helle (Estonian SL)

Schiffer, Claudia (German SL)

Shipley, Jenny (New Zealand SL)

Schumacher, Michael (German SL)

Sokolovski, Ernst (Estonian SL)

Stalin, Jossif (Estonian SL)

Stokoe, William C. (American SL)

Sundaravej, Samak (Thai SL)

Talts, Jaan (Estonian SL)

Toomas (Estonian SL)

Tõnurist (Lepp), Helvi (Estonian SL)

Uhlig, Anne (German SL)

Univer, Volmer (Estonian SL)

Yeltsin, Boris (Estonian/Russian SL) 


\section{ACKNOWLEDGEMENTS}

I hereby thank all Deaf informants Janis Golubenkov, Olga Golubenkova and Riina Kuusk. I would also like to thank for valuable information Estonian Sign Language interpreters Liivi Hollman and Regina Paabo. Many thanks for specifying explanations to French ethnologist Yves Delaporte and German ethnographer Anne Uhlig. I am also grateful to American folklorist Simon J. Carmel for source reference to the description of personal name sign of W. C. Stokoe. Heartfelt thanks to Rachel Sutton-Spence, British Sign Language and name signs researcher at Bristol University, for her suggestions on the more idiomatic uses of English in this article.

\section{NOTES}

1 This article is based on a presentation made at the 1317th meeting of the Learned Estonian Society on 27.05.2009. This present translation has been made on the basis of Estonian article Kuuljate isikute viipenimed ('Name signs for hearing people') published in the 2009 Yearbook of the Learned Estonian Society on pp. 118-155 (issued in 2010). This translation was supported by the European Union through the European Regional Development Fund (Centre of Excellence CECT).

${ }^{2}$ Finger spelling, also known as manual or finger or hand alphabet, is a visualisation of the letters of spoken language by hand configurations. Each letter corresponds to a fixed hand configuration. Finger alphabets vary by sign languages (see Carmel 1982 for different finger alphabets worldwide). In some (e.g. Estonian) sign language finger spelling is one-handed, in others (e.g. British, New-Zealand, and Turkish) twohanded. Several Estonian hand configurations have changed over the decades.

3 Fr. R. Kreutzwald printed this publication using the example of similar picture magazines Das Pfennig Magazine in Germany, The Penny Magazine in England, and Le Magazine Pittoresque in France. In the Estonian publication Kreutzwald used wood engravings of mostly German, but also of English origin (Hain 2006: 3). This may be the reason why the British finger alphabet ended up in an Estonian picture magazine.

4 Estonian Sign Language was officially acknowledged on 1 March 2007, after the relevant amendment to the Language Act (see Language Act) came into force.

${ }^{5}$ In cooperation with EFSLI, the Estonian Association of Sign Language Interpreters organised an annual ESFLI conference in Tallinn in September 2009.

${ }^{6}$ Appendix contains a list of well-known public figures, educators related to the Deaf, Estonian Sign Language interpreters and biblical figures, whose personal name signs have been examined in this article. The author does not disclose the verbal name form of 14 reference people.

7 This accounts for different name forms of a person in the same (e.g. Estonian) sign language. If some people have a similar name form in different sign languages, it will be considered as one name sign. 
8 The manuscript contains verbal descriptions of particular name signs, and the origin of the name sign, where possible. Some of the descriptions and figures with regard to personal name signs used in this article (author Deaf illustrator Jüri Laumets) are preserved in the folklore collection of Estonian Deaf folklore (EFA I 47, 93/120) in the Estonian Folklore Archives of the Estonian Literary Museum.

9 This applies to European communities, because e.g. American Deaf people prefer arbitrary initialised name signs. In sign languages with dominant descriptive name systems, Deaf people consider initialised name signs as preliminary forms of descriptive personal name signs. American Deaf people tend to associate descriptive personal name signs with childish nicknames (see also McKee \& McKee 2000: 27).

10 The German method (also known as the oral method) was used in the schools for the Deaf in Germany and England. This method was based on lip-reading and teaching oral speech. E. Sokolovski followed the example of German Deaf education.

11 The French method (also known as the manual method) involved both finger spelling and methodical or systemised signs when teaching Deaf children in the classroom. This was not a natural means of communication for Deaf children, but rather a visualisation of French language spoken at that time (signed old French).

${ }^{12}$ Yves Delaporte (born in 1944) is a French ethnologist. He was Research Director at the Centre national de la recherche scientifique (CNRS), and member of the Laboratory of Urban Anthropology (Laboratoire d'Anthropologie Urbaine). He spent almost twenty years studying the Lapps, mostly their clothing. Today he is focused on the studies of French Deaf community, and etymology of French and American Sign Language. Y. Delaporte has published substantial discussions on Lapps as well as on French Deaf culture and sign language. The illustration of the name sign of Y. Delaporte was received from him by e-mail on 18.10.2009.

${ }^{13}$ Päivi Rainò (Pimiä) (born in 1957) has graduated from the University of Helsinki. She has worked as a lecturer in a training programme for sign language interpreters and as a researcher of Finnish Sign Language (Kotimaisten kielten tutkimuskeskus). P. Rainò defended her Doctoral Thesis on Finnish personal name signs in 2004.

${ }^{14}$ Anne Uhlig (born in 1974) is a German ethnographer. She has worked at the State Ethnographic Collections of Saxony (SECS) in Leipzig, where she initiated and participated in a project, the objective of which was to provide Deaf and blind people with access to the permanent exhibition. After having studied American native people, she became interested in Deaf people as a language and cultural minority. In 2010 she defended her Doctoral Thesis Ethnographie der Gehörlosen. Kultur Kommunikation - Gemeinschaft (Universität Leipzig). The drawing of name sign for A. Uhlig was received from her by e-mail on 26.01.2010.

${ }^{15}$ Regina Paabo (Toom) (born in 1957), a long-term sign language interpreter, is the founder and current Chairwoman of the Estonian Association of Sign Language Interpreters. The topic of her Master's Thesis was the Development of the profession of sign language interpreter in Estonia. R. Paabo has compiled thematic sign glossaries, published written works on Estonian Sign Language, the Deaf community, and ethics of inner ear implantation. She started the training of Estonian Sign Language interpreters at the University of Tartu.

16 The same signing is used by Russian Deaf people. This is apparently a loan from Russian Sign Language. Russian signing Deaf people represent a minority in the Estonian Deaf community (cf. Swedish signing Deaf in Finland, etc.). In Estonian 
Sign Language an identical name sign referring to a pointy nose has been used for Estonian politician Eiki Nestor.

${ }^{17}$ In an official context, such as the TV news, two tendencies have been observed in terms of denoting people (both by Deaf people and by sign language interpreters): 1) finger-spelling of a personal name; 2) using a name sign. Finger-spelling of personal names on air seems more neutral, name signs are more colourful and represent more powerful reflections on Deaf culture.

${ }^{18}$ Interesting examples are found in Japanese Sign Language, where a personal name sign has the function of a toponym. Thus Japanese Deaf people denote Russia with place name sign RED SCAR (on the forehead). The place name sign has two parts: first the signer points to lips (i.e. red) and then brings a finger across the forehead (signifies a scar). The etymological explanation of this aforementioned toponym dates back to the times of Russian-Japanese War (1904-1905). According to a legend emperor Nikolai II was walking on the shore of a lake one day before the war. Suddenly a Japanese samurai drew his sword to kill the emperor. The attacker's hand slipped and he only scratched the forehead of the emperor. The story is well-known in Japanese oral history. Similarly, the personal name sign of Napoleon stands for France in Japanese Sign Language (Nuust 1989: 3).

${ }^{19}$ Illustrations of name signs of E. Honecker and E. Krenz were received from A. Uhlig by e-mail on 26.01.2010.

${ }^{20}$ This drawing (author Anne-Catherine Dufour) was published in the journal Revue du Collège de Psychanalyse, 1993, pp. 46-47. Illustration was received from Y. Delaporte by e-mail on 18.01.2010.

${ }^{21}$ Modification of the name sign of F. Mitterrand represents a colourful example of a name sign being a reflection of the course of life of the person. Mitterrand was given his first name sign (initial $\mathrm{M}$ as neutral, unoriginal name sign), when he became known among the Deaf as one particular politician among hundreds of others. The second version of the name sign was shaped after Mitterrand was elected president for the first time in 1974, and the Deaf people learned more about his character, personality and life. The name sign changed: initial $M$ was brought in front of the mouth, referring to his incisors (MITTERRAND-VAMPIRE). Even hearing people reach the same association when noticing strikingly sharp incisors. The third name sign was created before he was elected president for the second time in 1981, when he had his incisors removed in the interest of a successful election campaign. Y. Delaporte notes that in the case of these three last sign names it is impossible to say that one of them would be "more official" than others. For example, the third personal name sign of Mitterrand, which was apparently ironic and mocking, was used not only by the Deaf, but also by sign language interpreters who interpreted the news into French Sign Language on TV. (Personal e-mail correspondence with Yves Delaporte on 18.01.2010.)

${ }^{22}$ From personal e-mail correspondence with Yves Delaporte on 13.01.2010.

${ }^{23} \mathrm{Cf}$. e.g. the formation mechanism of nicknames for Estonian politicians (see EPPSS).

${ }^{24}$ Personal name signs are subject to play with name forming elements. Similar to other national sign languages, the phonological system of Estonian Sign Language is formed by hand shape, movement, place of performance or articulation of the sign and position of fingers and palm of hand. Meaning is given to the sign also by nonmanual components, such as: body position, facial expression, movement of head, 
body and eyes. The meaning of a sign is changed upon modification of one of the aforementioned parameters.

${ }^{25}$ In 2000, the sign language working group at the Estonian Bible Society, comprising Deaf people and sign language interpreters belonging to different Christian denominations, commenced the translation of the Gospel of Mark into Estonian Sign Language. In the course of translation it was considered reasonable to find appropriate personal name signs for Biblical figures, in addition to finger spelling their names. Different parts of the Bible have been translated into local sign language in many countries (e.g. in Finland, Sweden, Norway, Germany, etc.). The photographs of Biblical names used in this article originate from the manuscripts of the Estonian Sign Language working group on translation of the Gospel of Mark at the Estonian Bible Society.

\section{REFERENCES}

Carmel, Simon J. 1982. International Hand Alphabet Charts. 2nd edition. Rockville, MD: Studio Printing Incorporated.

Carmel, Simon J. 1996. Deaf Folklore. In: J. H. Brunvand (ed.) American Folklore: An Encyclopedia. Garland reference library of the humanities, Vol. 1551. New York \& London: Garland Publishing, Inc., pp. 197-200.

Colmenares, Klaus 2005. Aus der Bild-Zeitung vom 7.11.2005. Zum Lernen und Mittratschen. So heißen unsere Promis in Gebärden-Sprache. http://www.mglo.de/ inhalt/2005/bildzeitung_trube.htm, last accessed on 30 March 2011.

Delaporte, Yves 2002. Les sourds, c'est comme ça. Ethnologie de la surdimutité. Mission du Patrimoine ethnologique. Collection Ethnologie de la France, 23. Paris: Édition de la Maison des sciences de l'homme, pp. 52-55, 204-207, 313.

Eesti isikuviipenimed [Estonian Personal Name Signs]. Liina Paalese kogutud allikmaterjal, autori valduses. [Manuscript. Collected by L. Paales, held by the author.]

EFA = Eesti Rahvaluule Arhiiv [Estonian Folklore Archives]. Eesti viipekeelne pärimus. Käsikiri. [Estonian Deaf Folklore. Manuscript.] I 47, 93/120. Tartu: Eesti Kirjandusmuuseum. Eesti Rahvaluule Arhiiv. 2001.

EKLA = Eesti Kirjandusmuuseumi Kultuurilooline Arhiiv [Cultural History Archives of the Estonian Literary Museum.]

EPPSS = Eesti Poliitikute Poeetiliste Sünonüümide Sõnastik. [Glossary of Poetic Synonyms for Estonian Politicians.] Eesti Ekspress 22. 02. 2007. http:// paber.ekspress.ee/viewdoc/CBABB739D8F0FCD9C2257287004FADCB, access restricted.

Grigg-Langton, Kirsi 2009. An open letter for President Obama (ASL and subtitled). http://www.youtube.com/watch?v=67V8qWQd_EM, last accessed on $30 \mathrm{March}$ 2011.

Hain, Jüri 2006. Sajand eesti puugravü̈rri (1840-1940) klotsidel Eesti Rahvusraamatukogu kollektsioonist. [One hundred years of Estonian wood engraving (18401940) on the blocks: from the collection of the National Library of Estonia.] Tallinn: Eesti Rahvusraamatukogu, pp. 3-20. http://www.nlib.ee/html/digi/ puugravyyr/puugravyyr.pdf, last accessed on 30 March 2011. 
Hedberg, Tomas 1994. Name Signs in Swedish Sign Language: Their Formation and Use. In: C. J. Erting et al. (eds.) The Deaf Way: Perspectives from the International Conference on Deaf Culture. Washington: Gallaudet University Press 1994, pp. 416-424.

Hollman, Liivi 2010. Basic color terms in Estonian Sign Language. Dissertationes linguisticae Universitatis Tartuensis 14. Tartu: Tartu University Press.

Klima, S. Edward \& Bellugi, Ursula 1979. Wit and Plays on Signs. In: E. S. Klima \& U. Bellugi \& R. Battison et al. (eds.) The Signs of Language. Cambridge, MA: Harvard University Press, pp. 319-339.

Kreutzwald, Friedrich R. 1849. Ma-ilm ja mõnda, mis seal sees leida on. Tullosaks ja öppetlikkuks aeawiteks Ma-rahwale. IV and. [The world and something of what it contains IV]. Tartu, pp. 123-125. (Reprint Tallinn: Eesti Rahvusraamatukogu 2003.)

Kotsar, Juta \& Kotsar, Kaarel 1996. Eesti kurtide elu ajaraamat I. [Chronicles of the Estonian Deaf I.] Tallinn: Ühiselu, pp. 8-9.

Language Act = Elektrooniline Riigi Teataja [Electronic State Gazette.] In Estonian: http://www.riigiteataja.ee/ert/act.jsp?id=12796913, in English: http:// www.legaltext.ee/et/andmebaas/tekst.asp?loc=text\&dok=X30086K8\&keel=en \&pg=1\&ptyyp=RT\&tyyp=X\&query=keeleseadus, last accessed on 30 March 2011.

Maher, Jane 2002. Seeing language in Sign: The Work of William C. Stokoe. Washington: Gallaudet University Press, p. 133.

Markuse evangeelium eesti viipekeeles. Käsikiri. [Gospel of Mark in Estonian Sign Language. Manuscript]. Eesti Piibliselts.

McClure, Peter 1981. Nicknames and Petnames: Linguistic Forms and Social Contexts. Nomina, Vol. 5, pp. 63-76.

McKee, David \& McKee, Rachel L. 2000. Name Signs and Identity in Deaf Communities in New Zealand Sign Language. In: M. Metzger (ed.) Bilingualism and Identity in Deaf Communities. Washington: Gallaudet University Press, pp. 3-40.

Meadow, Kathryn P. 1977. Name Signs as Identity Symbols in the Deaf Community. Sign Language Studies, Vol. 16, pp. 237-246.

Mindess, Anna 1990. What Name Signs Can Tell Us about Deaf Culture. Sign Language Studies, Vol. 66, pp. 1-23.

Nuust, Valeri 1989. Jaapanist, teatrist ja keiser Nikolaist (Eesti Raadio ainetel). [About Japan, theatre and Nicholas II of Russia (according to Estonian Radio).] Kurtide Elu, March, No. 11/12, p. 3.

Paales, Liina 2004. Isikumärkide süsteemist eesti viipekeeles. [On the System of Person-Denoting Signs in Estonian Sign Language.] Keel ja Kirjandus, Vol. 3, pp. 201-208.

Paales, Liina 2008. Kohamärkide süsteem eesti viipekeeles. [System of toponymic signs in Estonian Sign Language.] In: T. Jaago (ed.) Ruumi loomine. Artikleid keskkonna kujutamisest tekstides. [Interpretations of the Environment in Texts.] Studia Ethnologica et Folkloristica Tartuensia 11. Tartu: Tartu Ülikooli Kirjastus, pp. 13-42.

Paales, Liina 2010. On the System of Person-Denoting Signs in Estonian Sign Language. Estonian Personal Name Signs. Sign Language Studies, Vol. 10, No. 3, pp. $317-335$. 
Piibel [Bible] 1999. Tallinn: Eesti Piibliselts.

Püve, Birgit 2002. Härra peaminister Vunts. [Mister Prime Minister Moustache.] Eesti Ekspress 11.07, No. 28 (657), pp. 18-19.

Rainò, Päivi 2000. Viittomanimistä ja nimentajusta. In: A. Malm (ed.) Viittomakieliset Suomessa. Helsinki: Finn Lectura, pp. 201-204.

Rainò, Päivi 2004. Henkilöviittomien synty ja kehitus suomalaisessa viittomakieliyhteisössä. [The emergence and development of personal name signs among sign language users in Finland.] Deaf Studies in Finland 2. CD-ROM. Helsinki: Kuurojen Liitto ry, pp 43-52, 79-87.

Rainò, Päivi 2005. Henkilöviittomien synty ja kehitus suomalaisessa viittomakieli$y$ hteisössä. [The emergence and development of personal name signs among sign language users in Finland.] Lektiot. Virittäjä 1, Verkkoliite, pp. 1-8. http://www.kotikielenseura.fi/virittaja/hakemistot/jutut/raino1_2005.pdf, last accessed on 30 March 2011.

Rutherford, Susan D. 1993. A Study of American Deaf Folkore. Burtonsville, MD: Linstok Press Dissertation Series, pp 129-135.

Strauss-Sameneh, Nicole 2001. Namensgebärden in der Palästinensischen Gebärdensprache III. Das Zeichen. Zeitschrift für Sprache und Kultur Gehörloser, Vol. 58, pp. 594-601.

Supalla, Samuel James 1992. The Book of Name Signs: Naming in American Sign Language. San Diego: Dawn Sign Press.

Suvi = Suomalaisen viittomankielen verkkosanakirja. [Finnish Sign Language Dictionary on the Internet.] Jeesus. 1138. http://suvi.viittomat.net/index.aspx?c= search;2\&type=res\&crt_fin=Jeesus, last accessed on 30 March 2011.

Thailand Prime Minister upset by sign language = Tai peaministrit vihastas viipekeel . Postimees. ELU24. 01.02.2008. http://www.elu24.ee/?id=9756, last accessed on 30 March 2011.

Tiersky, Roland 2003. François Mitterrand: a very French President. Lanham, MD: Rowman \& Littlefield, p. 298.

Vaik, Kristin 2006. Milline nimi on "oma"? [Which name is closest to the self?] Hortus Semioticus, No. 1, pp. 85-93. http://www.ut.ee/hortussemioticus/1_2006/pdf/ 1(2006)_vaik.pdf, last accessed on 30 March 2011.

Venemäki, Elina 2005. Nimittely helpottaa arkea. Ylioppilaslehti 02.09. http:// www.ylioppilaslehti.fi/2005/09/02/nimittely-helpottaa-arkea, last accessed on 30 March 2011.

Vuorijärvi, Riikka 2008. Luukkaan evankeliumi avautuu viittoen. Rauhan Tervehdys. Seurakuntalehti 06.03, No. 9, p. 4. http://www.rauhantervehdys.fi/liitteet/ rauhantervehdys-00010024-12.pdf, last accessed on 30 March 2011.

What's in Sign Name? Filipino Deaf from the Eyes of a Hearing Person: Issues, activities, experiences and technologies about Deaf People in the Philippines. http:// Deafphilippines.wordpress.com/2009/01/20/whats-in-a-sign-name, last accessed on 30 March 2011.

Yau, Shunchiu \& He, Jinxian 1990. How Do Deaf Children Get Their Name Signs During Their First Month in School? In: W. H. Edmondson \& F. Karlsson (eds.) Sign Language Research (SLR '87): Papers from the Fourth International Symposium on Sign Language Research. Hamburg: Signum, pp. 243-254. 